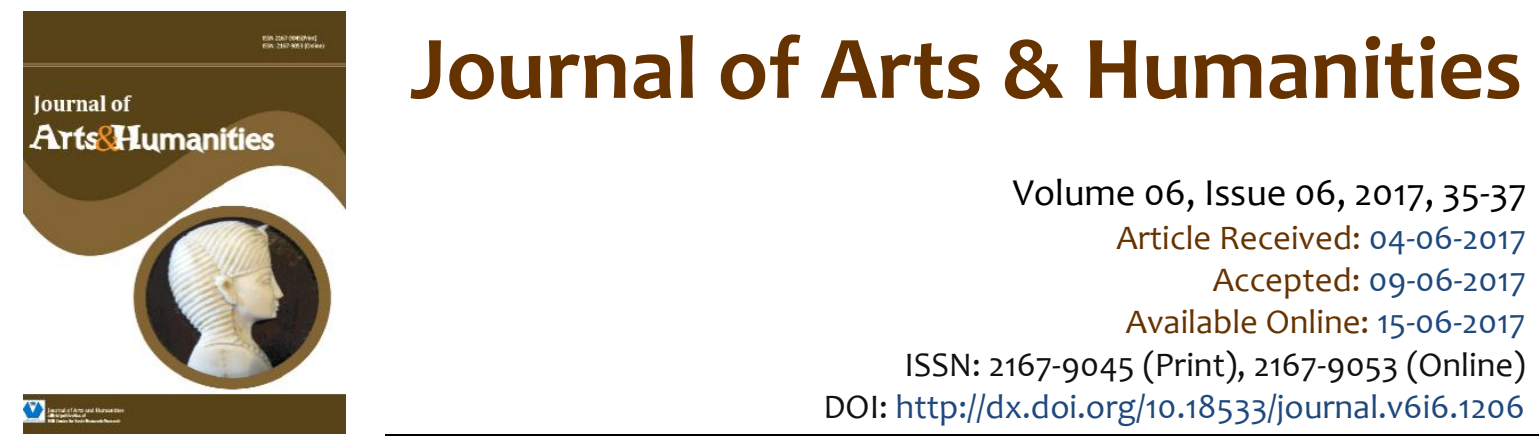

\title{
The Challenges of Refugees Protection
}

\author{
Dr Maysa Bydoon ${ }^{1}$
}

\begin{abstract}
The current crises and civil war in many countries, increasingly challenge the rapid growth of influx of refugees. More recently, as a matter of fact, the asylum issue is one of the most important issues in the international community that shed lights on a violation of refugees' rights and most importantly a safe area to live in. The article examines the refugee protection in light of the Convention relating to the Status of Refugees 1951 and Protocol relating to the Status of Refugees. It is true that such convention and its complementary protocol contribute in establishing the international law of refugee protection, however, its argues that the convention does not cover all people into danger in terms of refuges definition and principals of non refoulement.
\end{abstract}

Keywords: Convention, non refoulement, refugees.

This is an open access article under Creative Commons Attribution 4.0 License.

\section{Introduction}

Refugee status has been associated with World War II and the tragedies of mass destruction and the loss of life and property, making the international community is moving towards the adoption of protection to all who suffered and need a humanitarian aids.

Significant influx of refugees to many Arab countries in recent years needs a response to a crisis in terms of exploring solutions to help hosting countries deal with this problem and to shed light on the main international legal instruments for protecting refugees.

According to the United Nations High Commissioner for Refugees (UNHCR), Egypt, Iraq, Lebanon, and Jordan host the largest numbers of refugees among the Arab states.

This article discusses the fundamental challenges of refugee protection in terms of the legal instruments adopted by international community to protect refugees.

${ }^{1}$ Associate Professor of Public International law at the Faculty of law, AL-al Bayt University- Jordan 


\section{2. \\ The fundamental challenges of refugee protection}

International refugee law faces many fundamental challenges embodied in the definition of refugee and the nonrefoulement norm.

\subsection{The definition of refugee}

The term refugee under Article $1 \mathrm{~A}$, paragraph 1 of the 1951 convention determines the precise formulation of the term "refugee" scopes, as including only persons who have been disfranchised by their state on the basis and for reasons of race, religion, nationality, membership of a particular social group or because of their political opinions. Article $1 \mathrm{~A}$, paragraph 1 of the 1951 convention stated as follows:

- any person who is outside their country of origin and unable or unwilling to return there or to avail themselves of its protection, on account of a well-founded fear of persecution for reasons of race, religion, nationality, membership of a particular group, or political opinion. Stateless persons may also be refugees in this sense, where country of origin (citizenship) is understood as "country of former habitual residence". Those who possess more than one nationality will only be considered as refugees within the Convention if such other nationality or nationalities are ineffective (that is, do not provide protection).

The refugee must be "outside" his or her country of origin, and the fact of having fled, of having crossed an international frontier, is an intrinsic part of the quality of refugee, understood in its ordinary sense. However, it is not necessary to have fled by reason of fear of persecution, or even actually to have been persecuted. The fear of persecution looks to the future, and can also emerge during an individual's absence from their home country, for example, as a result of intervening political change. ${ }^{2}$

However, the adequacy and efficiency of the refugee convention definition is still debatable. ${ }^{3}$ It is worth noting that Article 1(D) 1951 convention exclude Palestinian Refugees in terms of receiving protection or assistance. It runs as follows "shall not apply to any persons who are at present receiving from organs or agencies of the United Nations other than the United Nations High Commissioner for Refugees protection or assistance"4

Fifteen years later, Protocol relating to the Status of Refugees 1967 expanded the scope of the 1951 Convention definition to include refugees from all regions of the world which has achieved the universality of the Convention definition of refugee status. ${ }^{5}$

\subsection{The nonrefoulement norm ${ }^{6}$}

The obligation imposed on states to respect the nonrefoulment principle is an important issue in terms of the protection of refugees.

\footnotetext{
${ }^{2}$ See Sjoberg, T., the powers and the persecuted: The Refugee problem and the intergovernmental committee on refuges (IGCR), 1938-47, (1991), Salmon, K., refugees in the cold war: toward a new international refugee in the early postwar era, 1991, 64-54.

3 Karen Musalo, Jennifer Moore and Richard A, Boswell: refugee law and policy a comparative and international approach, Carolina Academic Press, fourth edition, p. 36-46

${ }_{4}^{4}$ According to many estimates, during the six-day war between Israel and the Arab states in 1967, some 300,000 Palestinians moved from the West Bank to the East Bank in Jordan and to Syria, and from the Gaza Strip to Egypt and Jordan. Karen Musalo, Jennifer Moore and Richard A, Boswell: refugee law and policy a comparative and international approach, Carolina Academic Press, fourth edition, p. 36-46

${ }^{5}$ supra note 3, p. 36

${ }^{6}$ See UN document A/AC.96/INF.158 AT 9. Takkenberg, A and Tahabz,C.C ., The Collected Travaux Preparatiores Of The 1951 Convention Relating To The Status of refugees , 3 volumes, Dutch Refugee Council/European legal network on asylum , 1988. See also, Weis, P., territorial asylum, 6 Indian journal of international law1966, 173-183.
} 
The nonrefoulement principle means that no refugee should be returned to any country where he or she is likely to face persecution or torture. Article 33 of the 1951 Convention deals with Prohibition of expulsion or return ("refoulement") as follows:

- No Contracting State shall expel or return (" refouler ") a refugee in any manner whatsoever to the frontiers of territories where his life or freedom would be threatened on account of his race, religion, nationality, membership of a particular social group or political opinion.

- The benefit of the present provision may not, however, be claimed by a refugee whom there are reasonable grounds for regarding as a danger to the security of the country in which he is, or who, having been convicted by a final judgment of a particularly serious crime, constitutes a danger to the community of that country.

The scope of the principle of nonrefoulement applies as stated in article 33 of the 1951 Convention to refugees that mentioned on Article 1. Not only this but also the principle of nonrefolument applies to asylum seekers regardless the legal status of the asylum seeker and the way that the asylum seeker comes within the territory or jurisdiction of State ${ }^{7}$. The UNHCR Executive Committee affirmed that "the fundamental importance of the principle of non refoulement irrespective of whether or not individual have been formally recognized as refugees"8

It is worth noting that the protection of refugees embodied in the principle of nonrefoulement is not an absolute one. The principle of nonrefoulement is restricted by keeping safe the National Security and public order. article 33(2) provides states a clear justification for derogation to a refugee whom there are reasonable grounds for regarding as a danger to the security of the country in which he is, or who, having been convicted by a final judgment of a particularly serious crime, constitutes a danger to the community of that country. ${ }^{9}$

The question of risk raised the legal relationship between article 33and articles 1 of the 1951 convention in terms of the protection of non-refoulement. It is suggested that article 1 referred to examination at the frontier of those wishing to enter a contracting State, whereas article 33 was concerned with provision applicable at a later stage. The co-existence of these two possibilities was perfectly feasible. ${ }^{10}$ It is worth mentioning that the principles of natural justice and due process of law are required in application of the notion of particularly serious crime.

However, the right of a refugee to return to his or her country is another challenge of the refugee protection in terms of the freedom of movement as correctly maintained that:

When refugees reenter their country, the UNHCR attempts to achieve a durable solution in which the former refugees return to reintegrate in safety and dignity. It is important for the successful reintegration of returnees that they are able to reclaim ownership and possession of belongings, cars, offices, and land. The restitution of houses occupied by other individuals is often a problem faced by displaced people who return home. ${ }^{11}$

In conclusion, there are a Varity of other issues currently facing the refugee protection. As far as protection to refugees is concerned, it has been suggested that the scope of such protection should be broaden.

\footnotetext{
7 the UK House of Lords in 1987 reaffirmed the relation of refugee status and non refoulement as stated with reference to the travaux preparatories, that the non refoulement provision in article 33 was intended to apply to all persons determined to be refugees under article 1 of the convention, for more details see Goodwin-Gill, the refugee in international law, ClarendonPress. Oxford

${ }^{8}$ Ibid, p. 137

9 article $33(2)$

10 UN conference of Plenipotentiaries, summary records. UN doc. A/CONF.2/SR.35, P.22.

${ }^{11}$ supra note 3, p.72
} 